\title{
Environmentally Induced Under-Development of Seeds in Garden Pea and Its Underlying Factors
}

\author{
Akira Horibata1, Takuji Ito', Masayuki Kotani², Takahide Kawanishi², Hiroshi Shinto², \\ Kazuyoshi Tsuji ${ }^{2}$, Shigeki Kusu2 ${ }^{2}$, Tsuneo Kato ${ }^{{ }^{*}}$ \\ ${ }^{1}$ Faculty of Biology-Oriented Science and Technology, Kindai University, Kinokawa, Japan \\ ${ }^{2}$ Horticultural Experiment Center, Wakayama Research Center of Agriculture, Forestry and Fisheries, Gobo, \\ Japan \\ Email: *tkato@waka.kindai.ac.jp
}

Received 17 June 2016; accepted 15 July 2016; published 18 July 2016

Copyright (C) 2016 by authors and Scientific Research Publishing Inc.

This work is licensed under the Creative Commons Attribution International License (CC BY).

http://creativecommons.org/licenses/by/4.0/

(c) (i) Open Access

\section{Abstract}

Under-development of pea (Pisum sativum L.) seeds in normally developed pods, resulting in "unfilled pods", has been a serious problem in the greenhouse cultivation in Wakayama Prefecture, one of the major regions of pea cultivation in Japan. This phenomenon appears to be induced by low temperature and low solar irradiation during pea growing season. This study examined the relationship between this seed under-development and sucrose-to-starch metabolism in developing seeds and pods after flowering. The starch content, ADP-glucose pyrophosphorylase (AGPase) and sucrose synthase activities of a pea cultivar, Kishu-usui, were monitored through seed development in shading-treatment plot and in control plot. Results showed that the present treatment induced the depression of starch accumulation and AGPase activity in developing seeds compared with control, which might cause the occurrence of under-development of seeds and unfilled pods. Surplus carbohydrates from source organs might be stored in pod walls, as expected from higher starch level and AGPase activity in treated pod walls. The necessity of thermostable AGPase variants in pea to prevent the unfilled-pod problem was discussed.

\section{Keywords}

ADP-Glucose Pyrophosphorylase, Low Irradiation, Low Temperature, Starch Content, Sucrose Synthase, Unfilled Pods

\footnotetext{
${ }^{*}$ Corresponding author.
}

How to cite this paper: Horibata, A., Ito, T., Kotani, M., Kawanishi, T., Shinto, H., Tsuji, K., Kusu, S. and Kato, T. (2016) Environmentally Induced Under-Development of Seeds in Garden Pea and Its Underlying Factors. Agricultural Sciences, 7, 439-446. http://dx.doi.org/10.4236/as.2016.77045 


\section{Introduction}

In Japan, cultivars of garden pea (Pisum sativum L.) are performed mainly under greenhouse conditions in largescale. In Wakayama Prefecture, one of the major regions of pea cultivation in Japan, the growing season of pea generally ranges from late autumn to the next early spring, corresponding to relatively warm winter conditions in this region. Flowering period in this case ranges continuously from December to the next March. Pods were harvested after maturation also continuously until about May.

One of the serious problems in this pea cultivation in Wakayama is the frequently occurrence of seed abortion after flowering, resulting in so-called "unfilled pods" which look like normal pods in appearance but involve several under-developed seeds. These unfilled pods are difficult to distinguish from pods with well-developed seeds by eye-inspection in the shipment to markets. It, therefore, makes serious troublesome for pea growers and also consumers.

Kawanishi et al. [1] showed that the seed abortion in pea can be induced when pea plants were growing after flowering under low-intensity solar radiation (less than $23 \%$ of the control) and low air temperature (below $13^{\circ} \mathrm{C}$ ) particularly in the morning. They also showed that these environmental conditions influenced negatively only the percentage of under-developed seeds, but not the fertilization events. This is because the ploidy level of under-developed seeds was diploid from flow cytometry (personal communication). Therefore, some internal factors should be attributable to the under-development of seeds after fertilization.

In developing pea seeds, photoassimilates from source leaves are transported as a form of sucrose. Unloaded sucrose to sink apoplast is moved into developing embryo, and converted to UDP-glucose, glucose-1-phosphate and glucose-6-phosphate, sequentially. Glucose-6-phosphate is transferred via specific transporter to plastids, and again converted to glucose-1-phosphate, ADP-glucose and finally to starch [2]. Weigelt et al. [2] conducted RNA interference experiment to surpress ADP-glucose pyrophosphorylase (EC 2.7.7.27, AGPase) genes, which catalyzes the step from glucose-1-phosphate to ADP-glucose, and observed the decrease in starch accumulation and the increase in sucrose content. The significance of AGPase on starch accumulation in pea embryo has been demonstrated by several researchers [3]-[5]. Déjadin et al. [6] reported that the genetic variation in the activity of sucrose synthase (EC 2.4.1.13, SuSy), which catalyzes the step from sucrose to UDP-glucose, among nine pea genotypes mainly contributed to the variation in the rate of starch accumulation in pea embryos. These researches implied that the occurrence of under-developed seeds is associated with some environmentally induced disorders in sucrose-to-starch metabolism in developing pea seeds.

The present study examined the starch contents and enzyme activities relating to the sucrose-to-starch metabolism in the under-developed and normal seeds, as well as pod walls. The objective of this study was to understand the mechanism underlying the occurrence of under-developed seeds or unfilled pods of pea causing environmental conditions.

\section{Materials and Methods}

\subsection{Plant Materials, Cultivation and Shading Treatment}

A pea cultivar "Kishu-usui", was used as the material in this experiment. "Kishu-usui" is a local cultivar which has been cultivated dominantly in Wakayama Prefecture, Japan, and used as a parent of several cross breeding programs, because of its excellent performance. Immature seeds of this cultivar is harvested as fresh vegetables. Seeds of this cultivar were sown on 25 September, 2009, into cultivation beds in a greenhouse, after vernalization at $2^{\circ} \mathrm{C}$ for 20 days. Fertilizers were applied as basal dressing at a rate of $\mathrm{N}: \mathrm{P}_{2} \mathrm{O}_{5}: \mathrm{K}_{2} \mathrm{O}=11: 15: 11 \mathrm{~g} \mathrm{~m}^{-2}$, and as top dressing at late December, 2009 and middle February, 2010, at a rate of 3:4:3 $\mathrm{g} \mathrm{m}^{-2}$ at both periods.

To induce pods with under-developed seeds, a shading treatment was conducted. In the shading treatment plot, whole plants were covered by sheets of fine net, reducing light intensity approximately $38 \%$ of the non-treated condition from the start of flowering (from early December), while no shading treatment was done in the control plot. Temperature was kept at above $5^{\circ} \mathrm{C}$ in both plots during all growing season. Photoperiod and humidity were not controlled. Total of four and six plants were assigned as shading treatment plot and control plot, respectively. Flowering days were recorded for all of flowers individually.

\subsection{Determination of Matured Dry Weight and Starch Content in Seeds and Pod Walls}

On 9 March, 2010, all pods were sampled simultaneously from six plants (three in control and three in treatment 
plots), frozen in liquid nitrogen, and stored under $-80^{\circ} \mathrm{C}$ until used for determination of starch content. On 10 May, 2010, all of the pods were again sampled simultaneously from other four plants (three in control and one in treatment plots), frozen in liquid nitrogen, and stored under $-80^{\circ} \mathrm{C}$ until used for enzyme assay. The duration between the sampling day and flowering day in individual pod was regarded as days after flowering (DAF) of the seeds in the pods. A part of the sampled pods involving matured seeds (more than $50 \mathrm{DAF}$ ) in both treated and control plots were dried at $90^{\circ} \mathrm{C}$ for three days in an oven. Individual seed dry weights of all seeds involving under-developed ones were measured in both plots.

To determine starch content, a colorimetric method [7] was conducted. Frozen pod walls (approximately 1 gFW per sample) and seeds (approximately 0.75 gFW per sample) were separately measured their fresh weight, dissected into small pieces with a scalpel, incubated in $60 \%$ ethanol at $70^{\circ} \mathrm{C}$ for $15 \mathrm{~min}$, and thoroughly homogenized with a homogenizer (NS-55, Microtec Co., Ltd., Funabashi, Japan). After filtration through a paper filter (ADVANTEC No. 2, Advantec Toyo Kaisha Ltd., Tokyo, Japan), the residue remained on filter was dried completely in an oven. Ten $\mathrm{mL}$ of $7 \mathrm{~N} \mathrm{HClO}_{4}$ was added to a part of residue, and stirring for 10 min to make gelatinization. These samples were diluted with deionized water, filtrated through glass wool, and adjusted their volumes to be $200 \mathrm{~mL}$ with deionized water. After appropriate dilution, $1 \mathrm{~mL}$ each of $0.5 \% \mathrm{KI}$ and $0.001 \mathrm{~N} \mathrm{KIO}_{3}$ were added to $10 \mathrm{~mL}$ of each sample, and thoroughly mixing. Absorbance at $620 \mathrm{~nm}$ was measured after $5 \mathrm{~min}$ with a spectrophotometer (UV-1600, Shimazu Co., Kyoto, Japan) to determine the starch content. Potato starch (Sigma-Aldrich, Co., MO, USA) of known concentrations (0, 200 and $500 \mu \mathrm{g} 10 \mathrm{~mL}^{-1}$ ) was used as a standard calibration curve.

\subsection{Assay of Enzyme Activity in Seeds and Pod Walls}

For the extraction of enzyme fraction, a frozen single seed per pod and a part of pod wall (pericarp) which directly attached to the seed (up to $0.1 \mathrm{gFW}$ per sample) were individually and separately dissected into small pieces with a scalpel, placed into a Lysing Matrix D tube (MP Biomedicals LLC, OH, USA) together with $1 \mathrm{~mL}$ of extraction buffer consisting of $50 \mathrm{mM}$ HEPES/NaOH (pH 7.5), $2 \mathrm{mM}$ EDTA, $10 \mathrm{mM} \mathrm{MgCl}_{2}, 50 \mathrm{mM}$ 2-mercaptethanol, 12.5\% glycerol, 5\% PVP (polyvinylpyrrolidone)-40 (Sigma-Aldrich, Co., MO, USA). These tubes were equipped with FastPrep 24 (MP Biomedicals LLC, OH, USA) and homogenized for 60 sec at Speed = 60. The procedures hereafter to obtain course enzyme fraction were described in Kato et al. [8]. Enzyme assay in seeds and pod walls for SuSy and AGPase was followed the methods of Kato et al. [8]. Enzyme activity was expressed as mU mg protein ${ }^{-1}$. Protein concentration was measured using Protein Assay Kit (Bio-Rad Laboratories, CA, USA) with BSA as a standard.

\section{Results}

\subsection{Under-Development of Pea Seeds Due to Shading Treatment}

Figure 1 shows the frequency distribution of matured (more than 50 DAF) seed dry weight in the treatment (total of 86 seeds) and control plots (88 seeds). Given the seeds less than $75 \mathrm{mg} \mathrm{seed}^{-1}$ were under-developed, percentages of under-developed seeds were $48.8 \%$ in the treatment plot and $11.4 \%$ in the control. The difference in the percentage of under-developed seeds between the treatment and control plots was statistically significant $\chi^{2}=$ 27.39, $P<0.0001$ ) from a goodness of fit test. This result clearly demonstrated that under-development of pea seeds was certainly induced by the present shading treatment.

\subsection{Starch Contents in Seeds and Pod Walls}

In the control plot, starch contents of seeds linearly increased from the youngest stage (at approximately 25 DAF) to approximately 55 DAF to $60 \mathrm{DAF}$, and kept the highest level hereafter (Figure 2(a)). Therefore, it is adequate that the seeds of more than 50 DAF were judged as "matured" seeds, as above. Contrastingly, the starch contents in the treatment plot increased but obviously more slowly compared with the control plot, and reached lower levels than the control even in the oldest stage. The levels of starch content in treatment plot were significantly $(P<0.0001)$ lower than the control at the first and the second halves of growing seeds (tentatively set at $<$ $50 \mathrm{DAF}$ and $\geq 50 \mathrm{DAF}$, respectively) according to $t$-test (Table 1 ). For the starch content of pod walls (Figure 2(b)), the level in the control plot was just lower at the youngest stage than with those of seeds, and gradually decreased hereafter to undetectable level. On the other hand, the starch contents in the treatment plot were approximately the same level as pod walls in the control plot, and decreased moderately compared with the control 


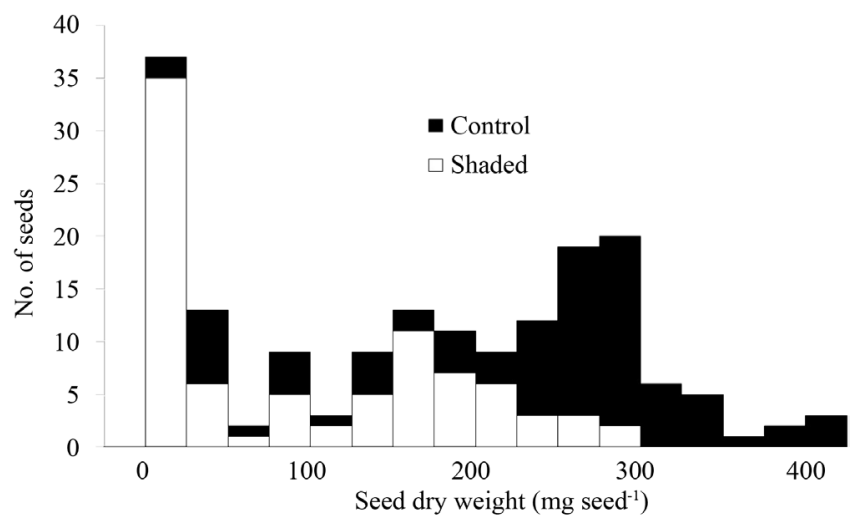

Figure 1. Frequency distributions of matures seed dry weight/seed in shading treatment plot and in control plot of a pea cultivar, "Kishu-usui".

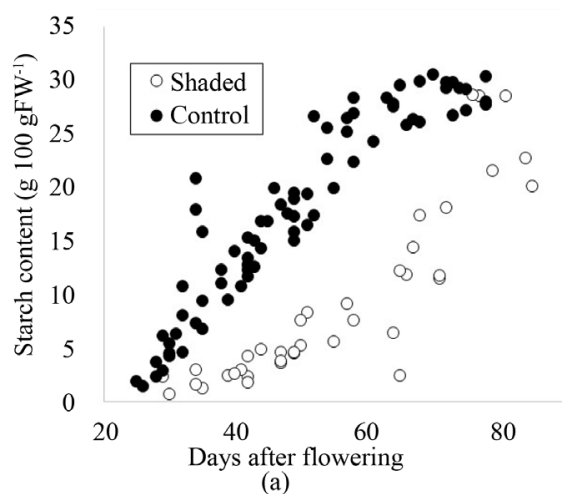

(a)

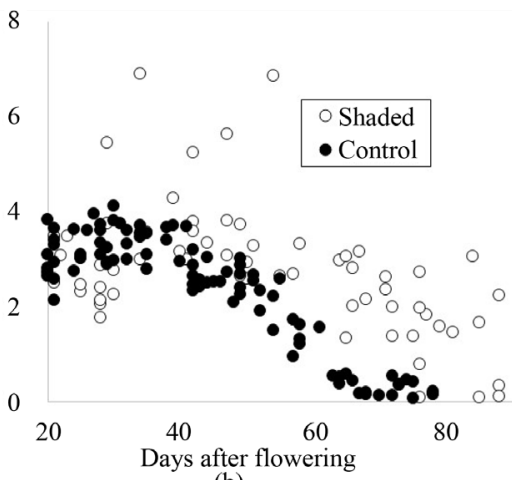

(b)

Figure 2. Changes in starch contents of developing seeds (a) and pod walls (b) in shading treatment plot and in control of a pea cultivar, "Kishu-usui".

Table 1. Starch content, activities of ADP-glucose pyrophosphorylase (AGPase) and sucrose synthase (SuSy) of developing seeds and pod walls in control and shading treatment plots in a pea cultivar, "Kishu-usui".

\begin{tabular}{|c|c|c|c|c|}
\hline Organ & Control & Treatment & $t$ & $P$ \\
\hline \multicolumn{5}{|c|}{ Strach content (g $100 \mathrm{gFW}^{-1}$ ) } \\
\hline \multicolumn{5}{|l|}{ Seed } \\
\hline$<50 \mathrm{DAF}$ & 11.4 & 2.9 & 6.075 & $<0.0001$ \\
\hline$\geq 50 \mathrm{DAF}$ & 26.2 & 14.2 & 7.286 & $<0.0001$ \\
\hline \multicolumn{5}{|l|}{ Pod wall } \\
\hline$<50 \mathrm{DAF}$ & 3.1 & 3.8 & 1.699 & 0.0928 \\
\hline$\geq 50 \mathrm{DAF}$ & 0.9 & 2.2 & 4.505 & $<0.0001$ \\
\hline \multicolumn{5}{|c|}{ AGPase (mU mg protein ${ }^{-1}$ ) } \\
\hline \multicolumn{5}{|l|}{ Seed } \\
\hline$<30 \mathrm{DAF}$ & 31.9 & 19.2 & 6.579 & $<0.0001$ \\
\hline$\geq 30 \mathrm{DAF}$ & 40.4 & 30.7 & 3.006 & 0.0063 \\
\hline Pod wall & 7.4 & 11.5 & 2.467 & 0.0389 \\
\hline \multicolumn{5}{|c|}{ SuSy (mU mg protein ${ }^{-1}$ ) } \\
\hline \multicolumn{5}{|l|}{ Seed } \\
\hline$<30 \mathrm{DAF}$ & 334.7 & 199.6 & 5.616 & $<0.0001$ \\
\hline$\geq 30 \mathrm{DAF}$ & 305.6 & 301.9 & 0.143 & 0.8874 \\
\hline Pod wall & 22.3 & 21.4 & 0.114 & 0.9123 \\
\hline
\end{tabular}

$P$, probability of $t$; DAF, days after flowering. 
and maintained a detectable level at the oldest stage. This resulted in the non-significant and significant differences at the first and the second halves, respectively, between control and treatment plots (Table 1). Several pod walls showed exceptionally high starch contents at young stage in the treatment plot. It is plausible that seed and pod-wall dry weights may show the same growth profiles as that of starch contents.

\subsection{Enzyme Activities in Seeds and Pod Walls}

During the linearly increasing phase (from 15 DAF to 45 DAF) of starch contents in seeds, the activities of sucrose-to-starch metabolizing enzymes, AGPase and SuSy, of seeds and pod walls in the treatment and control plots were monitored (Figure 3 and Figure 4). For AGPase, activities of seeds in the control plot gradually increased in the first half of this stage (tentatively set at $<30 \mathrm{DAF}$ ) and remained the final level (Figure 3(a)). Seeds in the treatment plot showed similar pattern as those in the control, but resulted in consistently lower values than the control plot during all stages. Mean activity of AGPase in the control plot was significantly $(P<$ $0.01)$ higher than those in the treatment plot both in the first half of this phase $(<30 \mathrm{DAF})$ and the second half ( $\geq 30 \mathrm{DAF}$ ), according to $t$-test (Table 1). On the contrary to the seeds, activities of AGPase in pod walls appeared to be constant despite of the difference in growth stage both in the treatment and control plots, although the values at initial growth stage were missing in pod walls (Figure 3(b)). Mean activity of AGPase in pod walls during all stage was significantly $(P<0.05)$ lower in the control plot than that in the treatment plot (Table 1).

For SuSy, activities of seeds in the control plot were not so greatly changed during growth stage examined (Figure 4(a)) compared with AGPase, resulting in no significant difference between the first and the second halves of this stage (Table 1). In the treatment plot, on the other hand, mean SuSy activity of seeds was significantly $(P<$ 0.0001) higher in the first half of the stage than the second half (Table 1), indicating obvious increase from a very

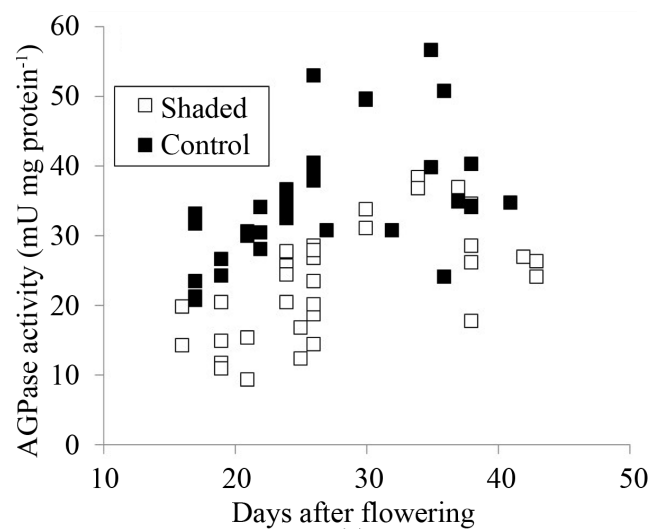

(a)

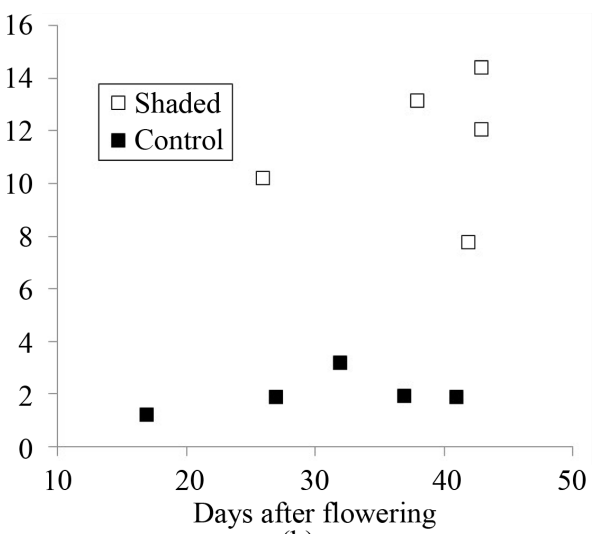

(b)

Figure 3. Changes in the activities of ADP-glucose pyrophosphorylase (AGPase) of developing seeds (a) and pod walls (b) in shading treatment plot and in control of a pea cultivar, "Kishu-usui".

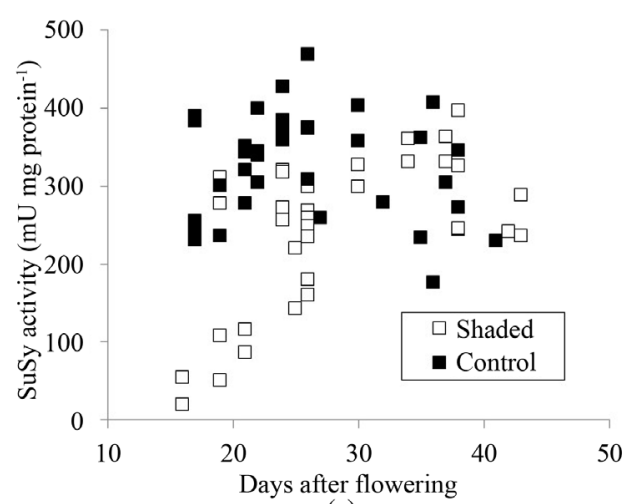

(a)

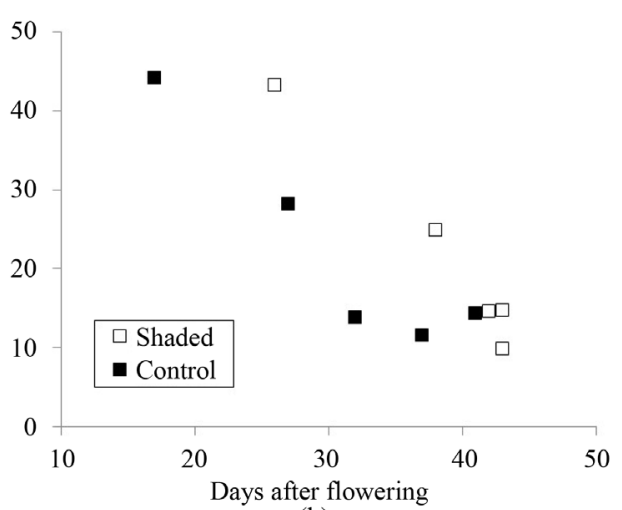

(b)

Figure 4. Changes in the activities of sucrose synthase (SuSy) of developing seeds (a) and pod walls (b) in shading treatment plot and in control of a pea cultivar, "Kishu-usui". 
low level to about the same as the control (Figure 4(a)). In pod walls, SuSy activity decreased clearly both in the treatment and control plots as pod growing (Figure 4(b)). This decreasing was just delayed in the treatment plot compared with the control plot. Mean activities in pod walls during all stages were not significantly different between the two plots (Table 1).

The clear decrease in seed starch content of the treatment plot, which corresponded to the occurrence of under-developed seeds, should be attributed, at least partly, to the decrease in seed AGPase activity, rather than SuSy. This is because an obvious parallelism between the profile of changes in starch content and AGPase activity in seeds (Figure 2(a) and Figure 3(a)). SuSy activity in the treatment plot certainly decreased at the first half of seed development, but was not different at the second half, compared with the control (Figure 4(a) and Table 1). The carbohydrates, mainly sucrose, from source organs could not be transported sufficiently to the seeds in the treatment plot due to the disorder of source-to-starch metabolism in developing seeds. These surplus carbohydrates might be inevitably stored in pod walls, resulting in a relatively higher level of starch in this organ (Figure 2(b)). This accumulation of starch was also suggested from higher level of AGPase activity in pod walls (Figure 3(b)). On the other hand, no apparent changes were found in the pod-wall SuSy activity in the treatment plot (Figure 4(b)), except for the delay of the profile.

\section{Discussion}

AGPase has been well known as a key enzyme of starch biosynthesis in developing endosperms and seeds, leaves and other starch accumulating plant organs [9]. In addition to its fundamental contribution to starch biosynthesis, AGPase plays an important role in the responses against temperature stress in several plants [10]. Influences of low temperature have not been fully examined in pea.

The present study may be the first trial to exhibit the relationship between AGPase activity and seed abortion, or unfilled pods, in developing pea seeds under low temperature and low solar irradiation conditions, although more data accumulation will be needed. In rice, Ahmed et al. [11] examined the effects of cold stress $\left(12^{\circ} \mathrm{C}\right)$ on the activity of sucrose-to-starch metabolism enzymes. They showed that low temperature reduced the activities of enzymes including AGPase, and excluding granule-bound starch synthase. This stress did not affect grain weight, but increased amylose content of endosperm.

Avoidance of seed abortion or unfilled pods in developing pea seeds under adverse conditions is basically provided to prevent these stresses through appropriate cultivation control. As one of the other ways, breeding of tolerant pea genotypes could be considered, although genetic variation for the occurrence of unfilled pods in pea remained not to be fully understood (personal communication). Saripalli and Gupta [10] reviewed the thermotolerant or thermostable variants of AGPase molecule in relation to the development of heat tolerant crops. These thermostable variants could be obtained from many kinds of amino acid substitution by mutagenesis in maize [12] [13], by transgenic approach to introduce altered AGPase large-subunit showing insensitivity against the inhibition by inorganic phosphate in wheat [14], rice [15], and maize [12]. Also in pea plants, these mutants with thermostable AGPase would be introduced in the future breeding program, while other important factors as sucrose transporters [16] and other enzymes in starch biosynthesis than AGPase [6] [17] [18] should be considered for this problem.

\section{Conclusion}

In Japan, particularly in Wakayama Prefecture, under-development of seeds in garden peas in greenhouse cultivation is one of the serious problems for pea growers, because this results in unfilled pods which showed normal appearance but include disordered seeds. This phenomena is caused by low solar irradiation and low temperature after flowering stage. The present study clarified that the under-development of pear seeds caused by the environmental factors were strongly associated with abnormal sucrose-to-starch metabolism in developing seeds and pods with decreased activities of relating enzymes, particularly of AGPase. Thermostable AGPases and their underlying alleles could be one of the genetic resources to overcome this problem, in addition to environmental control. This problem is not only peculiar to a local region in Japan, but also can occur in any places of garden pea cultivation.

\section{Acknowledgements}

We sincerely thank to T. Morita, Fac. Biology-Oriented Science and Technology, Kinki University, for his tech- 
nical assistance. This study was partly supported from the fund of the Strategic Research and Development

Plans in Wakayama Prefecture (2009-2011).

\section{References}

[1] Kawanishi, T., Shinto, H., Fukushima, F., Sato, S., Mihara, H., Nishimoto, H. and Azuma, T. (2010) Investigation of Environmental Factors Inducing Unfilled Pea Pods (Pisum sativum L.). (1) Effects of Shading and Temperature on the Development of Pod and Ovule. Horticultural Research (Japan), 9, 183-189 (in Japanese with English Abstract). http://dx.doi.org/10.2503/hrj.9.183

[2] Weigelt, K., Küster, H., Rutten, T., Fait, A., Fernie, A.R., Miersch, O., Wasternack, C., Neil Emery, R.J., Desel, C., Hosein, F., Müller, M., Saalbach, I. and Weber, H. (2009) ADP-Glucose Pyrophosphorylase-Deficient Pea Embryos Reveal Specific Transcriptional and Metabolic Changes of Carbon-Nitrogen Metabolism and Stress Responses. Plant Physiology, 149, 395-411. http://dx.doi.org/10.1104/pp.108.129940

[3] Burgess, D., Penton, A., Dunsmuir, P. and Dooner, H. (1997) Molecular Cloning and Characterization of ADPGlucose Pyrophosphorylase cDNA Clones Isolated from Pea Cotyledons. Plant Molecular Biology, 33, 431-444. http://dx.doi.org/10.1023/A:1005752311130

[4] Hylton, C. and Smith, A.M. (1992) The rb Mutation of Peas Causes Structural and Regulatory Changes in ADPGlucose Pyrophosphorylase from Developing Embryos. Plant Physiology, 99, 1626-1634. http://dx.doi.org/10.1104/pp.99.4.1626

[5] Smith, A., Bettey, M. and Bedford, I.D. (1989) Evidence That the $r b$ Locus Alters the Starch Content of Developing Pea Embryos through an Effect on ADP-Glucose Pyrophosphorylase. Plant Physiology, 89, 1279-1284. http://dx.doi.org/10.1104/pp.89.4.1279

[6] Déjadin, A., Rochat, C., Wuillème, S. and Boutin, J.P. (1997) Contribution of Sucrose Synthase, ADP-Glucose Pyrophosphorylase and Starch Synthase to Starch Synthesis in Developing Pea Seeds. Plant, Cell and Environment, 20, 1421-1430. http://dx.doi.org/10.1046/j.1365-3040.1997.d01-32.x

[7] Carter, G.H. and Neubert, A.M. (1954) Rapid Determination of Starch in Apples. Journal of Agricultural and Food Chemistry, 2, 1070-1072. http://dx.doi.org/10.1021/jf60041a003

[8] Kato, T., Shinmura, D. and Taniguchi, A. (2007) Activities of Enzymes for Sucrose-Starch Conversion in Developing Endosperm of Rice and Their Association with Grain Filling in Extra-Heavy Panicle Types. Plant Production Science, 10, 442-450. http://dx.doi.org/10.1021/jf60041a003

[9] Ballicora, M.A., Iglesias, A.A. and Preiss, J. (2004) ADP-Glucose Pyrophosphorylase: A Regulatory Enzyme for Plant Starch. Photosynthesis Research, 79, 1-24. http://dx.doi.org/10.1023/B:PRES.0000011916.67519.58

[10] Saripalli, G. and Gupta, P.K. (2015) AGPase: Its Role in Crop Productivity with Emphasis on Heat Tolerance in Cereals. Theoretical and Applied Genetics, 128, 1893-1916. http://dx.doi.org/10.1007/s00122-015-2565-2

[11] Ahmed, N., Maekawa, M. and Tetlow, I.J. (2008) Effects of Low Temperature on Grain Filling, Amylose Content, and Activity of Starch Biosynthesis Enzymes in Endosperm of Basmati Rice. Australian Journal of Agricultural Research, 59, 599-604. http://dx.doi.org/10.1071/AR07340

[12] Hannah, C.L., Futch, B., Bing, J., Shaw, J.R., Boehlein, S., Stewart, J.D., Beiriger, R., Georgelis, N. and Greene, T. (2012) A shrunken-2 Transgene Increases Maize Yield by Acting in Maternal Tissues to Increase the Frequency of Seed Development. The Plant Cell, 24, 2352-2363. http://dx.doi.org/10.1105/tpc.112.100602

[13] Boehlein, S.K., Shaw, J.R., Stewart, J.D., Sullivan, B. and Hannah, L.C. (2015) Enhancing the Heat Stability and Kinetic Parameters of the Maize Endosperm ADP-Glucose Pyrophosphorylase Using Iterative Saturation Mutagenesis. Archives of Biochemistry and Biophysics, 568, 28-37. http://dx.doi.org/10.1016/j.abb.2015.01.008

[14] Simdansky, E.D., Meyer, F.D., Blakeslee, B., Weglarz, T.E., Greene, T.W. and Giroux, M.J. (2007) Expression of Modified ADP-Glucose Pyrophosphorylase Large Subunit in Wheat Seeds Stimulates Photosynthesis and Carbon Metabolism. Planta, 225, 965-976. http://dx.doi.org/10.1007/s00425-006-0400-3

[15] Sakulsingharoj, C., Choi, S.B., Hwang, S.K., Edwards, G.E., Bork, J., Meyer, C.R., Preiss, J. and Okita, T.W. (2004) Engineering Starch Biosynthesis for Increasing Rice Seed Weight: The Role of the Cytoplasmic ADP-Glucose Pyrophosphorylase. Plant Science, 167, 1323-1333. http://dx.doi.org/10.1016/j.plantsci.2004.06.028

[16] Tegeder, M., Wang, X.D., Frommer, W.B., Offler, C.E. and Patrick, J.W. (1999) Sucrose Transport into Developing Seeds of Pisum sativum L. The Plant Journal, 18, 151-161. http://dx.doi.org/10.1046/j.1365-313X.1999.00439.x

[17] Bhattacharyya, M., Martin, C. and Smith, A. (1993) The Importance of Starch Biosynthesis in the Wrinkled Seed Shape Character of Peas Studied by Mendel. Plant Molecular Biology, 22, 525-531. http://dx.doi.org/10.1007/BF00015981 
[18] Craig, J., Lloyd, J.R., Tmlinson, K., Barber, L., Edwards, A., Wang, T.L., Martin, C., Hedley, C.L. and Smith, A.M. (1998) Mutations in the Gene Encoding Starch Synthase II Profoundly Alter Amylopectin Structure in Pea Embryo. The Plant Cell, 10, 413-426. http://dx.doi.org/10.2307/3870598

\section{Submit or recommend next manuscript to SCIRP and we will provide best service for you:}

Accepting pre-submission inquiries through Email, Facebook, LinkedIn, Twitter, etc. A wide selection of journals (inclusive of 9 subjects, more than 200 journals)

Providing 24-hour high-quality service

User-friendly online submission system

Fair and swift peer-review system

Efficient typesetting and proofreading procedure

Display of the result of downloads and visits, as well as the number of cited articles

Maximum dissemination of your research work

Submit your manuscript at: http://papersubmission.scirp.org/ 